\title{
En mann i 70-årene med hypertensjon og akutte brystsmerter
}

\author{
En mann i begynnelsen av 70-årene var nylig kneoperert da han fikk \\ akutt innsettende retrosternale smerter og ble innlagt i sykehus. Et \\ sjeldent funn kunne forklare symptomene - eller var funnet tilfeldig?
}

En sprek mann i begynnelsen av 70-årene ble innlagt $i$ sykehus etter tre episoder med akutte retrosternale smerter. Første smerteepisode inntraff om morgenen innleggelsesdagen idet han skulle gå på toalettet. Han la seg ned, og smertene ga seg etter fem minutter. Pasienten ble etter dette liggende i sengen i noen timer. Da han så forsøkte å reise seg opp igjen, kom de samme smertene tilbake, med varighet av noen minutter. Ambulanse ble tilkalt, og han fikk sitt tredje smerteanfall idet han reiste seg for å gå inn $i$ den. I ambulansen hadde han god effekt av morfin, oksygen, nitroglyserin og aspirin og var smertefri ved ankomst akuttmottaket.

Pasienten hadde kjent hypertensjon. Hans faste medisiner var valsartan/hydroklortiazid og atorvastatin. Han hadde et beskjedent alkoholforbruk og hadde sluttet å røyke for over 30 år siden. Det var ingen kjente allergier. Tre uker før den aktuelle innleggelsen var han blitt operert med kneprotese på høyre side. Både peri- og postoperativt forløp var ukomplisert. Etter operasjonen og frem til det aktuelle hadde han brukt dalteparin 5000 IE $1 \times 1$ som tromboseprofylakse og smertestillende $i$ form av tramadol og paracetamol ved behov.

Ved innkomst var pasienten smertefri og respiratorisk ubesværet. Blodtrykket var $125 / 85 \mathrm{~mm} \mathrm{Hg}$, pulsen 78 og oksygenmetningen i arterieblod $\left(\mathrm{SaO}_{2}\right) 98 \%$ uten ekstra oksygentilførsel. Elektrokardiogram viste ingen tegn til akutt iskemi. Auskultasjon av hjerte og lunger var normal. Buken var bløt og uøm med normale tarmlyder. Det var et reaksjonsløst operasjonsarr og ødemer på fremsiden av høyre kne.

Det ble tatt normal blodgass på avdelingen. Blodprøvene viste hemoglobin $9,9 \mathrm{~g} / 100$ $\mathrm{ml}(11,7-15,3 \mathrm{~g} / 100 \mathrm{ml})$, hematokrit 0,29 (0,40-0,50), C-reaktivt protein $26 \mathrm{mg} / \mathrm{l} /<4$ $\mathrm{mg} / \mathrm{l})$, senkningsreaksjon $42 \mathrm{~mm}(1-12 \mathrm{~mm})$, leukocytter $5,4 \cdot 10^{9} / \mathrm{l}\left(3,5-10,0 \cdot 10^{9} / \mathrm{l}\right)$, trombocytter $596 \cdot 10^{9} / \mathrm{l}\left(145-390 \cdot 10^{9} / \mathrm{l}\right)$, alkalisk fosfatase $166 \mathrm{U} / \mathrm{l}$ (35-105 U/l) og D-dimer $18,5 \mathrm{mg} / \mathrm{l}(<0,4 \mathrm{mg} / \mathrm{l}$ )

D-dimer er en uspesifikk markør som kan være forhøyet ved ulike tilstander, for eksempel ved hyperkoagulabilitet eller økt fibrinolyse, ved leversykdom, malignitet, blødning, inflammasjon, etter traume eller etter operasjon.

Det er kjent at nivået av D-dimer, trombocytter og C-reaktivt protein kan øke etter større ortopediske inngrep, som hofte- og kneprotesekirurgi. Ved mistanke om dyp venetrombose i forbindelse med slike inngrep måles D-dimer de påfølgende dagene. Det er mellom postoperative dag 1 og dag 3 at man forventer de høyeste verdiene av D-dimer og trombocytter (1). Pasienten vår ble innlagt tre uker etter gjennomgått protesekirurgi, så de høye D-dimerverdiene kunne mest sannsynlig ikke relateres til inngrepet. Det var ingen mistanke om dyp venetrombose, da han kun hadde et lokalisert ødem relatert til et reaksjonsløst operasjonsarr på fremsiden av høyre kne. I tillegg sto han fortsatt på dalteparin.

Lett anemi og forhøyet senkningsreaksjon ble tolket som et postoperativt funn. CRP-nivået var lett forhøyet, men det var ingen tegn til systemisk eller lokal sårinfeksjon. De kliniske symptomene med brystsmerter og D-dimer på $18,5 \mathrm{mg} / 1$ gjorde at man primært mistenkte aortadisseksjon, lungeembolisme (selv med normal blodgass) eller en intraabdominal blødning. Det ble bestilt CT thorax med lungeembolismeprotokoll og CT-angiografi av totalaorta. Siden vi ikke kunne utelukke blødning, ble dalteparin nullet inntil CT-undersøkelsene var gjort og vurdering av disse forelå.

CT thorax med lungeembolismeprotokoll viste ingen tegn til lungeembolisme. CT-angiografi totalaorta viste en $3 \mathrm{~cm}$ lang disseksjon i arteria mesenterica superior ut i første høyresidige gren. Det var ingen disseksjon $i$ aorta for øvrig (fig 1).

Karkirurgisk avdeling ble kontaktet for råd om den videre oppfølgingen. De anbefalte å observere pasienten i 2-3 dager for eventuell utvikling av magesmerter og tarmiskemi. Dalteparin skulle seponeres.

Pasienten ble observert $i$ avdelingen i tre dager uten antikoagulasjonsbehandling. Under sykehusoppholdet hadde han ingen kostholdsrestriksjoner, han var mobilisert og smertefri hele observasjonstiden. Han har ikke hatt plager i ettertid.

\author{
Monica Chahal-Kummen \\ og forebyggende medisin \\ Medisinsk klinikk \\ Jørgen Joakim Jørgensen \\ Karavdelingen \\ og \\ Avdeling for traumatologi \\ Oslo universitetssykehus
}

monica.chahal.kummen@gmail.com Avdeling for endokrinologi, sykelig overvekt 


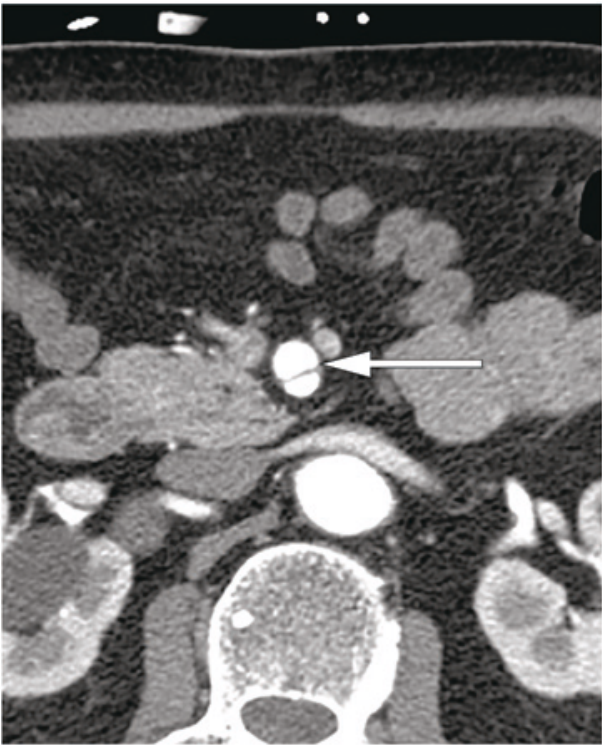

a

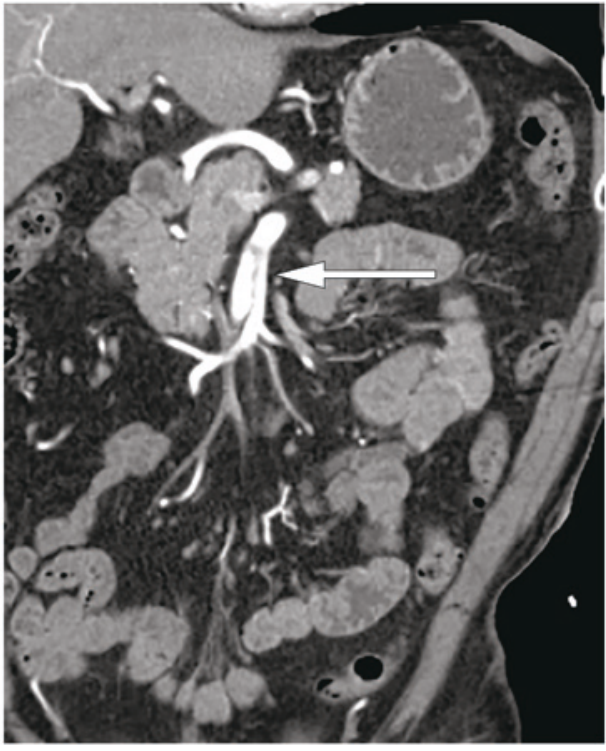

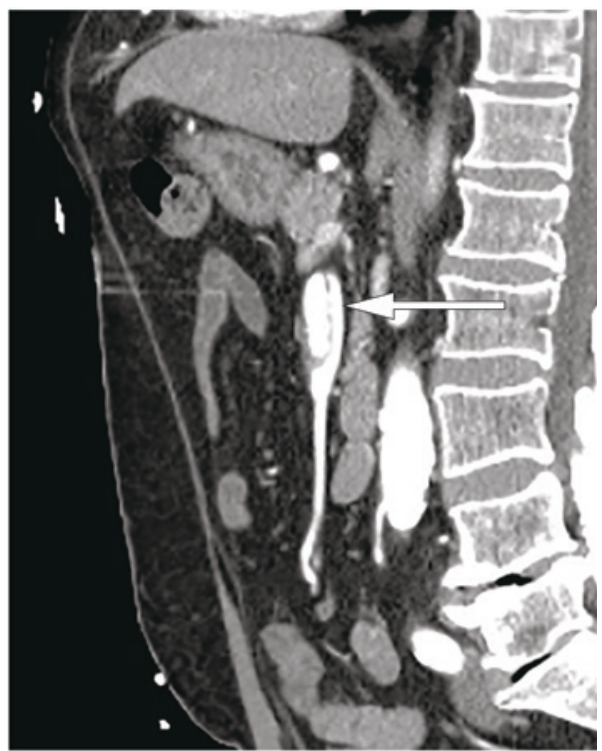

Figur 1 CT-angiografi totalaorta. a) Aksialt, b) koronalt og c) sagittalt snitt av arteria mesenterica superior-disseksjon (piler)

På grunn av det sjeldne, interessante funnet ble det gjort litteratursøk i Pubmed for å få kjennskap til andres erfaringer og begrunnelser for tiltak. Den gjennomgående anbefalingen om kontroll etter seks måneder gjorde at vi bestemte oss for å kontrollere pasienten med CT-angiografi. Denne viste uforandrede forhold, uten tegn til progrediering.

\section{Diskusjon}

Disseksjon av a. mesenterica superior ble første gang beskrevet av Bauersfeld i 1947 (2). Spontan isolert disseksjon av denne arterien er en sjelden tilstand (3-7), i litteraturen er det beskrevet under 100 tilfeller. Tilstanden rammer flest menn. De er gjerne i midten av 50-årene, ofte uten kjente risikofaktorer.

Foruten spontan disseksjon uten kjent årsak finnes kjente årsaker som bindevevssykdommer (Marfans sykdom, Ehlers-Danlos sykdom), karsykdommer som aterosklerose, (pseudo-)aneurismer, fibromuskulær dysplasi, cystisk medianekrose, segmentell arteriell mediolyse samt periarteriell inflammasjon (som kan ses ved kolecystitt eller pankreatitt). I tillegg kan slik disseksjon ses ved stumpt traume og ved graviditet (5-8).

Vår pasient var i 70-årene. Gjennomsnittsalder ved disseksjon av a. mesenterica superior er 50 år, og det kan være mulig at pasienten hadde hatt disseksjonen i lengre tid og at den nå representerte et tilfeldig funn ved den aktuelle innleggelsen. Pasienten hadde kjent hypertensjon, men ingen tidligere historie med traume, abdominal kirurgi eller alvorlig karsykdom.

A. mesenterica superior utløper fra abdo- minalaorta rundt $1-1,5 \mathrm{~cm}$ nedenfor avgangen til truncus coeliacus. Dens forgreninger forsyner pancreas, kaudale del av duodenum og resterende tynntarm, coecum og appendix, colon ascendens og store deler av colon transversum. Blodgjennomstrømmingen er på rundt $500 \mathrm{ml} / \mathrm{min}$ og påvirkes av måltidsrytme, fysisk aktivitet, blodtrykk, blodsukkernivå og hormoner som thyreoideahormoner, adrenalin, glukagon, vasopressin og somatostatin $(9,10)$. Proksimalt er arterien fiksert bak caput pancreatis, mens den er mer mobil distalt. Det er i den kurvede overgangen mellom fiksert og mobil del av arterien at de fleste disseksjoner oppstår. Området er spesielt utsatt for endringer i blodgjennomstrømming (f.eks. ved hypertensjon), men også for de fysiologiske tarmbevegelsene etter et måltid. Dette kan gi økt hemodynamisk stress og risiko for skade av intima. Slik intimaskade ses hos $70 \%$ av pasientene $(5-7,11,12)$.

Disseksjon med stenosering av opptil $60 \%$ av den sanne lumen kan tolereres uten at det forårsaker akutt tarmiskemi, på grunn av kollateral sirkulasjon fra truncus coeliacus og a. mesenterica inferior $(9,13,14)$. En stenose av a. mesenterica superior på 50-70\% (målt med dupleksultralyd) kan ofte gi symptomer når det $\mathrm{i}$ tillegg foreligger okklusjon av truncus coeliacus eller a. mesenterica inferior $(9,13)$. Vår pasient hadde disseksjon til første høyresidige gren, uten affeksjon av andre grener. Den sanne lumen var åpen $\mathrm{og}$ uten stenosering, og det var ingen trombosering av den falske lumen.

Pasienter med a. mesenterica superiordisseksjon kan være asymptomatiske, men også oppleve akutte magesmerter lokalisert til epigastriet eller venstre flanke, med eller uten oppkast $(6,15,16)$. Magesmertene kan komme av tarmiskemi, intraperitoneal blødning som skyldes ruptur av disseksjonen eller på grunn av inflammasjon rundt selve disseksjonen (5). Hvis disseksjonen er trombosert og tromben(e) beveger seg distalt, kan de forårsake mesenteriell iskemi, noe som vil gi pasienten svært sterke magesmerter, som i tillegg gjerne blir verre etter inntak av mat. Pankreatitt kan oppstå dersom disseksjonen sprer seg ut i forgreningen til pancreas (6).

Vår pasient var innlagt med brystsmerter, men smertene kunne like gjerne være epigastriesmerter, uten at man på det tidspunkt la vekt på å avklare dette. Om smertene kan relateres til funnet av a. mesenterica superior-disseksjon er usikkert. Han kan ha hatt disseksjonen i mange år, og CT-angiografifunnet kan ha vært tilfeldig. Like fullt kan smertene, som pasienten oppfattet som retrosternale brystsmerter, ha hatt sitt utspring fra epigastriet og muligens vært forårsaket av a. mesenterica superior-disseksjonen.

A. mesenterica superior-disseksjon avdekkes ofte som et tilfeldig funn på CT abdomen (12). Den ses bedre på CT-angiografi enn på kateterangiografi $(4,5)$, da sistnevnte ikke vil vise en eventuell totalt trombosert falsk lumen (5). På CT-angiografi kan man se økt diameter, intimalesjon, trombose av falsk lumen, intramuralt hematom eller $ø \mathrm{kt}$ fettinfiltrasjon i segmenter rundt arterien $(5,8)$. Kateterangiografi vil allikevel være bedre enn CT-angiografi for demonstrering av dobbelt lumen og kollateral blodgjennomstrømming og vil derfor ha størst betyd- 
ning når pasientens tilstand forverres og det må avgjøres om han trenger kirurgisk eller endovaskulær behandling $(5,16)$.

Alternativene for behandling er konservativ (med eller uten antikoagulasjonsmidler), endovaskulær eller kirurgisk (17). Asymptomatiske innlagte pasienter med tilfeldig påvist disseksjon uten tegn til tarmiskemi observeres i sykehuset. Pasienter med magesmerter behandles konservativt med eller uten antikoagulasjonsmidler og tarmhvile så lenge det ikke foreligger mistanke om tarmiskemi. Anbefalingene vedrørende observasjonstid i sykehus er 1-2 uker. Anbefalinger for type og varighet av antikoagulasjonsbehandling varierer også, med 3-4 uker for heparin og 3-4 måneder for warfarin $(12,16-20)$.

Ved vurdering av vår pasient ble det ikke anbefalt antikoagulasjonsbehandling, men kun observasjon med tanke på tarmiskemi. $\mathrm{Vi}$ avsto fra antikoagulasjonsbehandling fordi det var usikkert om funnet var relatert til det aktuelle sykdomsbildet eller om det var et tilfeldig funn.

Endovaskulær stentbehandling utføres ved progredierende disseksjon (kompresjon av sanne lumen $>80 \%$ og økning av aneurismediameter $>2 \mathrm{~cm}$ ), progredierende symptomer $>24$ timer til tross for konservativ behandling og når pasienten har symptomer på tarmiskemi (infeksjonstegn, økende magesmerter, sirkulasjonssvikt) initialt ved innleggelsen. Endovaskulær stentbehandling av a. mesenterica superior ble første gang utført av Leung og medarbeidere i $2000(3,18)$.

Åpen kirurgi kan være indisert ved symptomer som varer ved over 24 timer på tross av medikamentell behandling, etter mislykket endovaskulær stentbehandling, ved påvist tarmnekrose peroperativt og ved alvorlig blødning, for eksempel etter aneurismeruptur (18).

Det naturlige forløpet til a. mesenterica superior-disseksjon er oftest ett av følgende:

- Ingen eller liten avgrenset progrediering av disseksjonen med trombosering av den falske lumen

- Progrediering av disseksjonen til distale avgreninger av a. mesenterica superior

- Ruptur gjennom adventitia

- Ekspanderende falsk lumen som fører til obstruksjon av den sanne lumen

Anbefalt kontroll for kirurgisk eller endovaskulært behandlet a. mesenterica superior-disseksjon er CT-angiografi etter én og seks måneder. Ved konservativ behandling av disseksjonen anbefales det kontroll etter seks måneder (ev. tidligere, avhengig av pasientens sykehistorie). Etter seks måneder kan tilstanden være stabilisert. Ved behov for videre oppfølging utover dette anbefales kontroll hver 6.-12. måned, individuelt basert $(15,16,18,21,22)$.

\section{Konklusjon}

A. mesenterica superior-disseksjon er en sjelden tilstand som kan ha et svært alvorlig utfall. Den rammer oftest menn i midten av 50-årene og påvises tilfeldig eller på grunn av akutte magesmerter. Disseksjonen kan kompliseres med trombosering, ruptur eller mesenteriell iskemi.

Behandlingen er enten konservativ, med eller uten antikoagulasjonsmidler, endovaskulær eller kirurgisk. Pasienten bør følges opp til tilstanden har gått i regress eller er stabilisert. Kunnskapen og erfaringen rundt a. mesenterica superior-disseksjon er begrenset. Likevel er det viktig å kjenne til tilstanden som en sjelden, men alvorlig differensialdiagnose ved akutt abdomen og/eller akutte brystsmerter.

Pasienten har gitt samtykke til at artikkelen blir publisert.

\section{Monica Chahal-Kummen (f. 1980)}

er lege i spesialisering og forsker. Forfatter har fylt ut ICMJE-skjemaet og oppgir ingen interessekonflikter.

\section{Jørgen Joakim Jørgensen (f. 1974)}

er spesialist i karkirurgi og overlege. Forfatter har fylt ut ICMJE-skjemaet og oppgir ingen interessekonflikter.

\section{Litteratur}

1. Hughes SF, Hendricks BD, Edwards DR et al. Lower limb orthopaedic surgery results in changes to coagulation and non-specific inflammatory biomarkers, including selective clinical outcome measures. Eur J Med Res 2013; 18: 40.

2. Bauersfeld SR. Dissecting aneurysm of the aorta; a presentation of 15 cases and a review of the recent literature. Ann Intern Med 1947: 26. 873-89.

3. Leung DA, Schneider E, Kubik-Huch R et al. Acute mesenteric ischemia caused by spontaneous isolated dissection of the superior mesenteric artery: treatment by percutaneous stent placement. Eur Radiol 2000; 10: 1916-9.

4. Kim JH, Roh B-S, Lee YH et al. Isolated spontaneous dissection of the superior mesenteric artery: percutaneous stent placement in two patients. Korean J Radiol 2004: 5: 134-8.
5. Sakamoto I, Ogawa Y, Sueyoshi E et al. Imaging appearances and management of isolated spontaneous dissection of the superior mesenteric artery. Eur J Radiol 2007; 64: 103-10.

6. Watring NJ, Smith CM, Stokes GK et al. Spontaneous superior mesenteric artery (SMA) dissection: an unusual cause of abdominal pain. J Emerg Med 2010; 39: 576-8.

7. Park YJ, Park C-W, Park KB et al. Inference from clinical and fluid dynamic studies about underlying cause of spontaneous isolated superior mesenteric artery dissection. J Vasc Surg 2011: 53: 80-6.

8. Suzuki S, Furui S, Kohtake $\mathrm{H}$ et al. Isolated dissection of the superior mesenteric artery: CT findings in six cases. Abdom Imaging 2004; 29: 153-7.

9. Perko MJ. Duplex ultrasound for assessment of superior mesenteric artery blood flow. Eur J Vasc Endovasc Surg 2001; 21: 106-17.

10. Netter FH. Atlas of human anatomy. Philadelphia PA: Saunders, 2011: 286-8.

11. Solis MM, Ranval TJ, McFarland DR et al Surgical treatment of superior mesenteric artery dissecting aneurysm and simultaneous celiac artery compression. Ann Vasc Surg 1993; 7: 457-62.

12. Gobble RM, Brill ER, Rockman CB et al. Endovascular treatment of spontaneous dissections of the superior mesenteric artery. J Vasc Surg 2009; 50 : 1326-32

13. Casella IB, Bosch MA, Sousa WO Jr. Isolated spontaneous dissection of the superior mesenteric artery treated by percutaneous stent placement: case report. J Vasc Surg 2008; 47: 197-200.

14. Totsugawa T, Kuinose M, Ishida A et al. Spontaneous dissection of the superior mesenteric artery as a rare cause of acute abdomen: report of two cases. Acta Med Okayama 2009; 63: 157-60.

15. Carter R, O'Keeffe S, Minion DJ et al. Spontaneous superior mesenteric artery dissection: report of 2 patients and review of management recommendations. Vasc Endovascular Surg 2011: 45: 295-8.

16. Morris JT, Guerriero J, Sage JG et al. Three isolated superior mesenteric artery dissections: update of previous case reports, diagnostics, and treatment options. J Vasc Surg 2008; 47: 649-53.

17. Cho BS, Lee MS, Lee MK et al. Treatment guidelines for isolated dissection of the superior mesenteric artery based on follow-up CT findings. Eur J Vasc Endovasc Surg 2011; 41: 780-5.

18. Min S-I, Yoon K-C, Min S-K et al. Current strategy for the treatment of symptomatic spontaneous isolated dissection of superior mesenteric artery. J Vasc Surg 2011; 54: 461-6.

19. Lamprecht G. Trabold T, Gregor M et al. Spontaneous, self-limited, non-atherosclerotic dissection of the superior mesenteric artery. Eur J Gastroenterol Hepatol 2003; 15: 437-9

20. Nagai T, Torishima R, Uchida A et al. Spontaneous dissection of the superior mesenteric artery in four cases treated with anticoagulation therapy. Intern Med 2004; 43: 473-8

21. Park YJ, Park KB, Kim D-I et al. Natural history of spontaneous isolated superior mesenteric artery dissection derived from follow-up after conservative treatment. J Vasc Surg 2011; 54 1727-33

22. Yun WS, Kim YW, Park KB et al. Clinical and angiographic follow-up of spontaneous isolated superior mesenteric artery dissection. Eur J Vasc Endovasc Surg 2009; 37: 572-7.

Mottatt 12.12. 2014, første revisjon innsendt 23.3. 2015, godkjent 18.5. 2015. Redaktør: Lise Mørkved Helsingen. 